\title{
الابعاد المختلفة لتطور المسكن الريفى بمحافظة سوهاج
}

\section{زينب عوض عبد الحميا}

قسم بحوث المجتمع الريفى ـ معهد بحوث الارشاد الزر اعى والتتمية الريفية، مركز البحوث الزر اعية، الجيزة، مصر

Received: Oct. 21,2017

Accepted: Oct. 29,2017

المسنخخاص

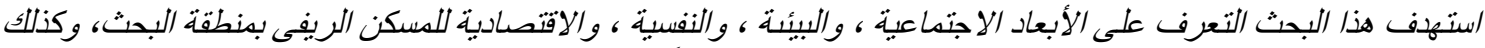

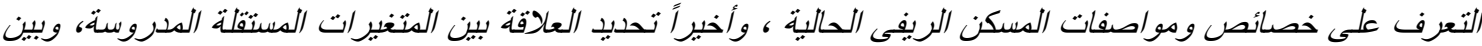

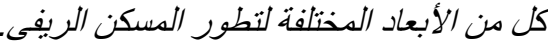

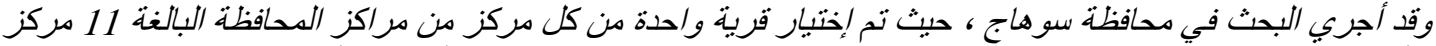

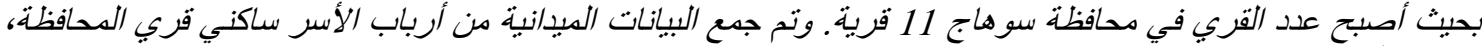

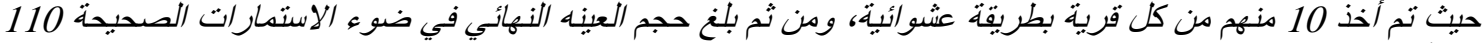

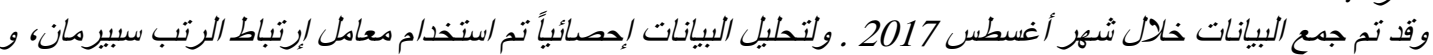
رب أسرة

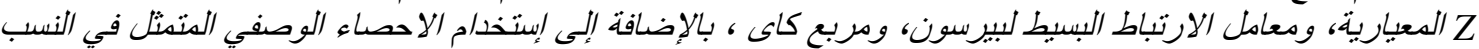

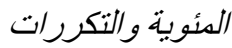
وقد توصل البثث إلى النتاتج التالية :

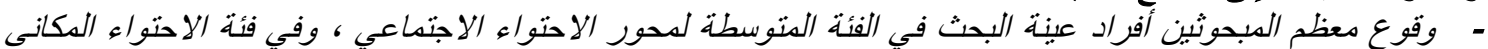

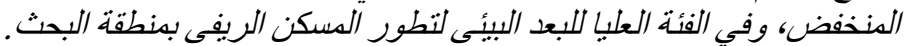

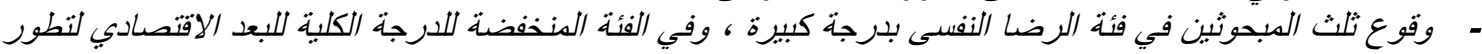

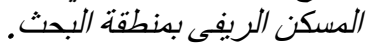

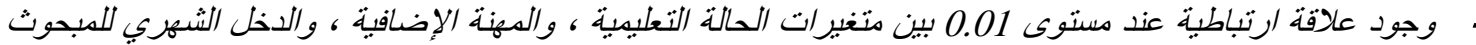

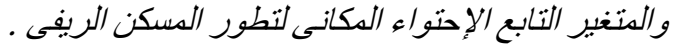

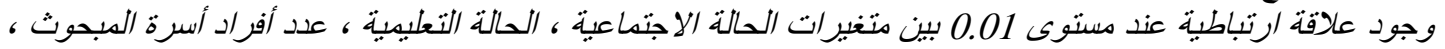

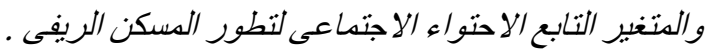

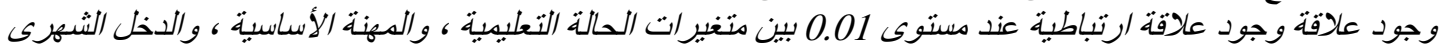

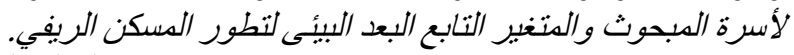

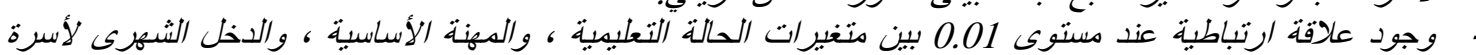

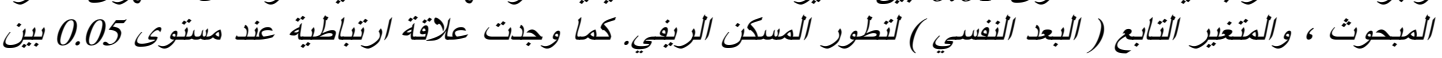

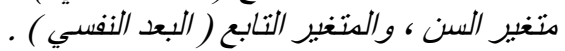

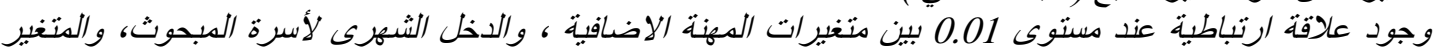

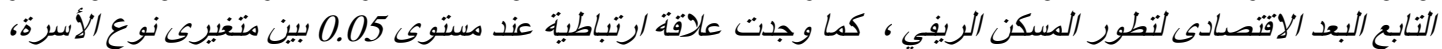

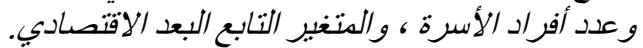

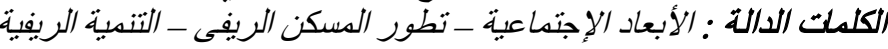

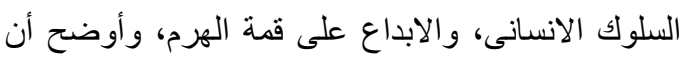

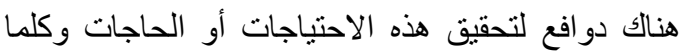

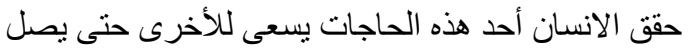

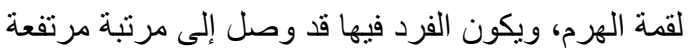
حقق فيها كل الاحتباجات الإنسانية السابقة وبدأ مجالاً

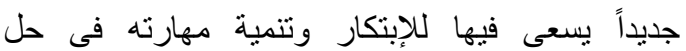
المشكلات ، ولكن التغيرات و المشكلات التى قد تقابل

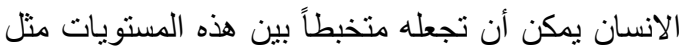
خلل العلاقات الاجتماعية كالطلاق أو فقدان الوظيفة.

\section{المقدمة ومشكلة الار اسة}

تعتبر الاحتياجات الانسانية ضرورية وهامة وبدون

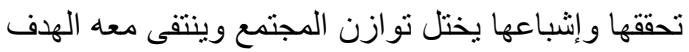
الذى من أجله خلق الله هذه الدنيا، ولذا فقد اهتم العديد من

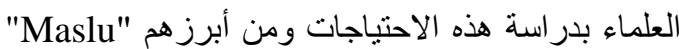

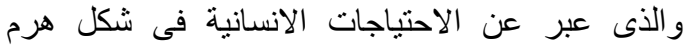
خماسى متدرج يبدأ من الاحتياجات الفسيولوجية الأساسية

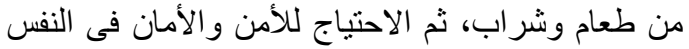

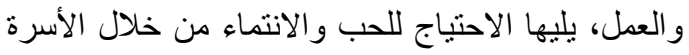
و الأصدقاء، ثم الاحتياج لتقدير الذات والثقة والاحترام، الأناه و أخير اً يأتى تحقيق الذات من خلال تربع الاخلاقيات على لألى 
و لاشك أن كل أو بعض هذه الاحتباجات قد نطور عبر الزمن وتأثز بعوامل إجتماعية و إقتصادية بل الإن وسياسية ساهنت في تغير التركيبة السكانية والمكانية و العمر انية فى المجتمع المصرى عامة، والريفى خاصة،

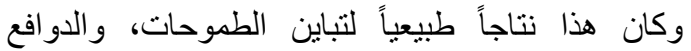
و الاحتياجات الانسانية ، و هناك العديد من مجالات العلوم التى تتاولت بالدراسة العلاقة بين الإنسان والبيئة التى الإن بعيش فيها ، ومنها مجال علم النفس الاجتماعي البيئى

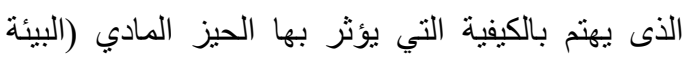
الفيزيقية: المسكن) على المكون النفسي والاجتماعي (شخصية وعلاقات الفرد مع أفراد أسرته)" لذا وجد أن الناعي الفئ هذا المجال ، يركز بشكل خاص على العلاقة الموجودة بين الفرد و المسكن، باعتبار ها علاقة تأثير وتأثر ، بحيث التيث تنشا بين أي إنسان ومكان سكنه علاقة خاصة ذات أبرات أبعاد سيكولوجية واجتماعية. فالإنسان عند اختبار مكان لإقامة مسكنه، مهما كانت مكانته وموقعه الاجتماعي و الثقافي، لإني، ينولا بينه وبين ذللك الموقع حوار خاص يتضمن مفهومه للحيز، ويجسد كامل معالم هويته. لذلك يجمع الباحثون و

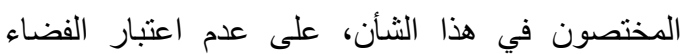
المنزلي" مجرد مساحة أو مكان مميز فقط، بل هو جملة

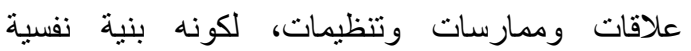
و اجتماعية تعبر عن شخصية صاحبها، حيث بمكن القول أن التنظيم و التغيير في البناء، ماهو إلا تنظيم وتغير لذات

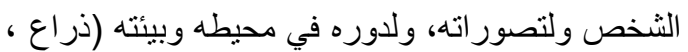
. (2017

http://elearn.univ(biskra.dz/mod/resource/view.php?id=2374 2017-10-1
وتمثل حاجة الانسان إلى المأوى احتياجًا انسانيًا لايجب إغفاله، وقد تطور المأوى من صورته البدائية

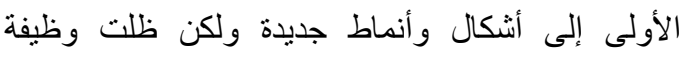
المأوى الأساسية ثابتة خلال التاريخ الانسانى كله وهى

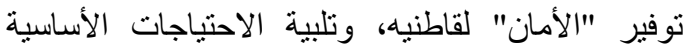
الأخري التي ذكر ها ماسلو في هرم الاحتياجات إن لم تكن

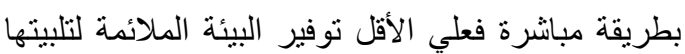
(بسيونى : 2009، 24 ). وعليه فقد أصبحت العلاقة التبادلية بين الانسان والمسكن حقيقة علمية مسلماً بها، فتأثير المسكن على الئي الانسان و على صحته البدنية والنفسية إما سلباً أو إيجاباً

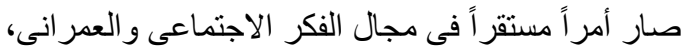
فالمسكن الملائم من حيث التهوية والمساحة والانارة يساعد الانسان على القيام بمسئولياته الفردية والاجتماعية، أما إذا عانى ضيق المكان وزيادة درجة التكس وفقدان الخصوصية وتدنى البيئة المعمارية و العمرانية المحيطة به فإن ذلك يجعل منه إنساناً غير سوى وأكثر إستعداداً للإنحراف الاجتماعى بصوره

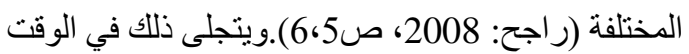
الراهن بظهور العديد من مشكلات الانحراف والسرقة وضعف الانتماء.

وفى إطار تصنيف الاحتياجات الانسانية السابقة وحاجة الانسان إلى المأوى كاحتياج أساسى يمكن القول

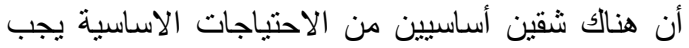

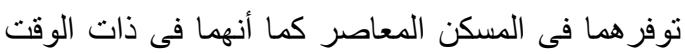
شقين مؤثرين فى تصميم المسكن وهما الاحتياجات الانسانية و الاحتياجات المادية و هما موضحان بالشكل 1 بهن (بسيونى: 2009، ص:31). 


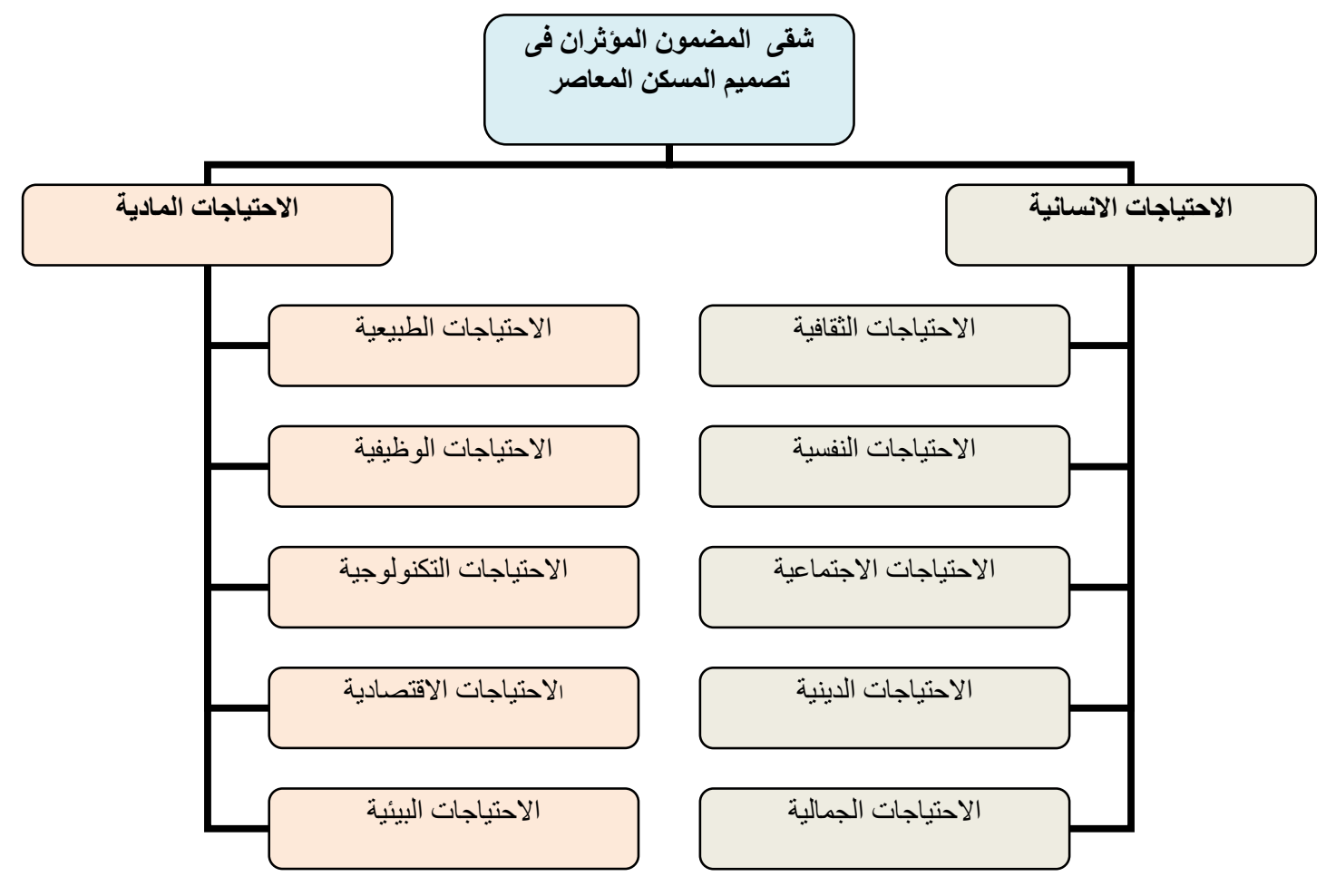

شكل1: الاحتياجات الأساسية المؤثرة على تصميم المسكن المعاصر

تستخدم أيضاً كجرن أثناء موسم الحصاد ويطل على لـى

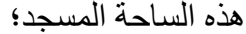
3) وثالث هذه العناصر المقابر وهى تكون بعيداً عن المياه في منطقة جافة.

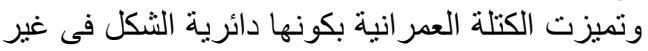
إنتظام، يحيط بها طريق خارجى يطلق عليه داير "الناحية" النئي

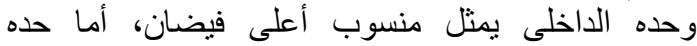

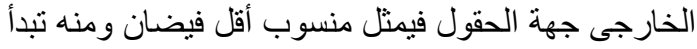

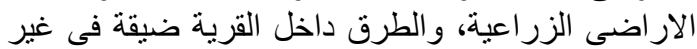

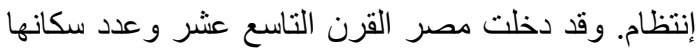

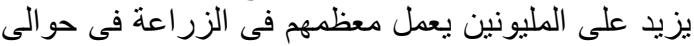

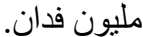

\section{المرحلة الثانية (القرن الـ19-منتصف القرن الـ}

تميزت هذه المرحلة بإقامة المشروعات الكبرى، فى والى الكي

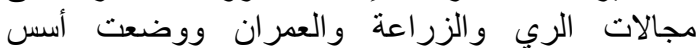

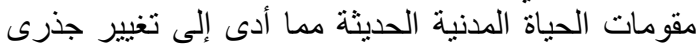

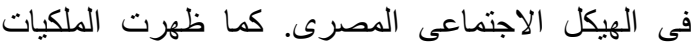

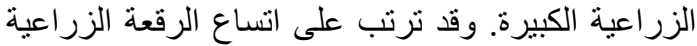

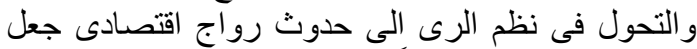

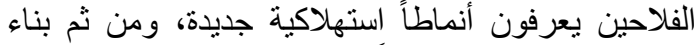
بيوت أفضل و أكثر اتساعاً وبدأت نظهر الأسقف الخثبية

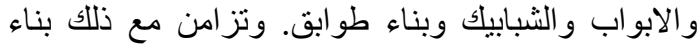

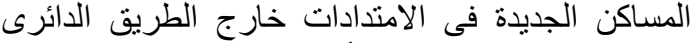
للقرية والبناء من الطوب الأحمر وتسكنها الثريحة العليا
وتثير اسماعيل (2005 ، 49 ) آن أن شعور الانسان

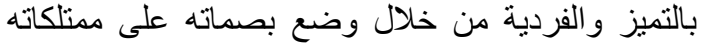

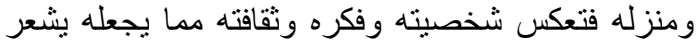
بالفخر و السعادة و الرضعا النفسي و والروحى.

وفى ضوء هذه العلاقة بين الإنسان و البيئة التى يعيش

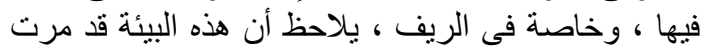
بمر احل عديدة من التغيير و التطوير داخل القرئ القرية المصرية ( راجح: 2007، ص صن: 254-269).

المرحلة الاولى (حتى بلاية القرن التاسع عشر)

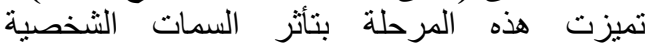
للمصريين بوجود نهر النيل والذى أسهر فى سيادة مهنة

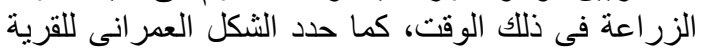

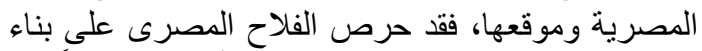

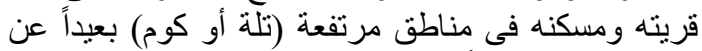

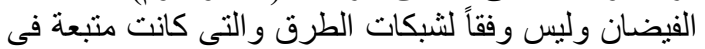
مجتمعات أخرى. وكانت القرية تنكون من ثلاث عنات عناصر في رئيسبة هـى: 1) المساكن وهى بيوت صغيرة مكونة من حجرة أو أكثر

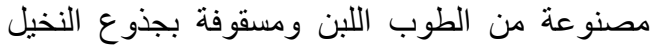

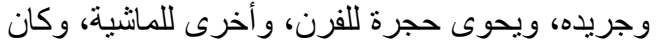
يتم تخزين الحطب فوق الاسطح والذى يسهم فى عزل اللى على حرارة الصيف عن المسكن؛ 2) و والساحة منعددة الاغراض ال ونك وهى تقع فى منطقة متوسطة من مساكن القرية وتستخدم فئ الاغر فئراض الاجتماعية، وتستخدم في يوم أسبو عياً كسوق، كما لأخرا 
يتبين مما سبق ضرورة إعادة النظر فى التخطيط العمرانى للقرى ووقف الزحف العشوائى، وتطوير النظام

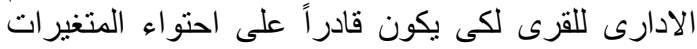

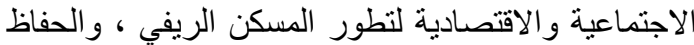
على هوية القرية ومن هذا المنطلق تتمحور مشكلة البحث الرئ

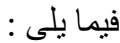

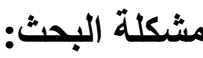

يعد احتياج الانسان للمسكن من أهم احتياجاته الفطرية الاساسية، لانه يوفر له الحماية، والأمن، والأمان، وهناك الك الهان الهان

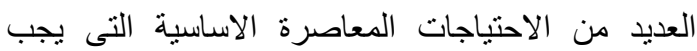
توافرها بالمسكن حتى يعبر عن المفهوم السليم للسكن و السكينة التى يتمناها الانسان، ومن هذه الاحتياجات ماهو فطرى متأصل داخل النفس البشرية، وماهو متغير بتغير المكان أو الزمان، وهناك العديد من التغيرات التى حدثت في نمط المسكن و ارتفاعه واحتوائه على المرافق الأساسية، وفي مواد البناء المستخدمة، كما تغير نظام

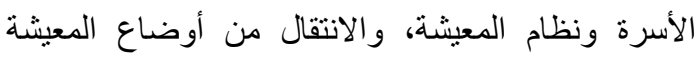
الريفية التقليدية إلى أوضاع جديدة زادت معها منطلبات

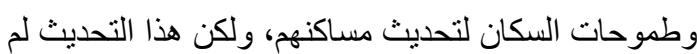
يكن بالثكل الذى يحافظ على موارد القرية الدصرية

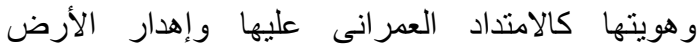
الزراعية، وتراجع الدور الإجتماعى للقرية ، ويحتاج الأمر إعادة توزيع السكان وتوازنهم مع الموارد، لحماية الارض الزراعية من الامتداد العمرانى عليها، كما يحتاج الأمر في ضوء اتجاهات التغيير الحادثة لمجتمع القرية إجراء العديد من الدراسات التى تعطى صورة واضحة لحال القرية والمسكن الريفي الان حتى يمكن تحديد الشكل الهناسب من التخطيط العمرانى الذى يجب مراعاته مستقبلا للحفاظ على هوية المسكن الريفي، وهوية القرية المصرية، وفي نفس الوقت اثباع احتباجات الريفيين

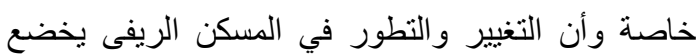
للعديد من الأبعاد سواء اجتماعية أو اقتصادية أو بيئية فيختلف التكوين العام للمنزل الريفي تبعًا للحالة الاقتصادية لسكانه وتكوينهم الاجتماعى، و هكذا تختلف مشكلة الاسكان

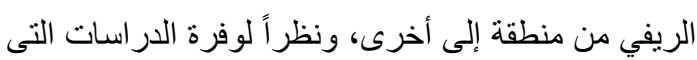

من مجتمع القرية والعاملين بمهن غير زراعية، وكانت

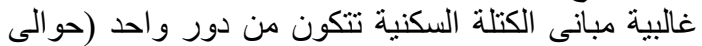
\%70) ، وبعضها من دورين وتسكنها عادة الأسر الممتدة،

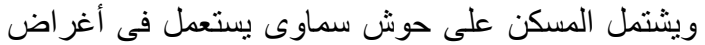

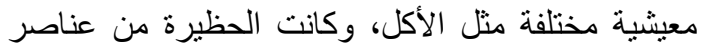

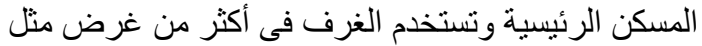

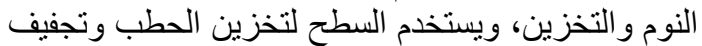
بعض الحاصلات الزراعية. والحو ائط فى الكين الكسكن القديم

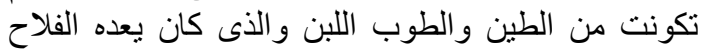

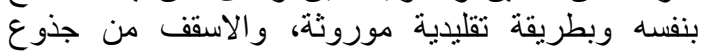
الثجر أو العروق الخشبية.

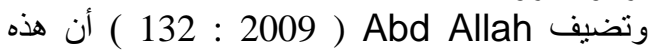
الطريقة البسيطة في بناء المنازل ومشاركة أفراد الأسرة

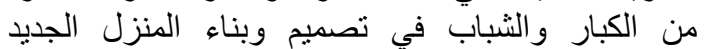
والمشاركة في تكاليف بنأية من شأنه أن يساعد على تلى تقوية الروابط الاجتماعية بين الثخص و عائلته وقبيلته .

المرحلة الثالثة ( من منتصف القرن العثرينحتى الان)

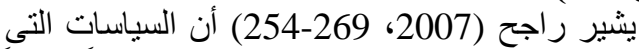

انتهجت فى العقود الخمسة الماضية قد أثرت تأثير أ جذرياً

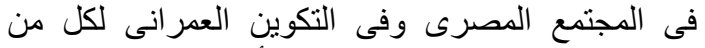
القرية و المدينة على حد سو اءع، ومن أهم ملامح هذا التها التغيير

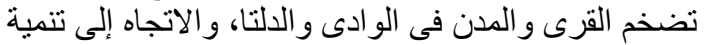

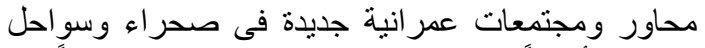

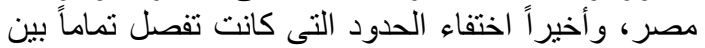

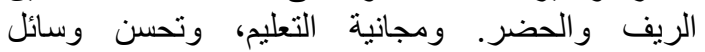

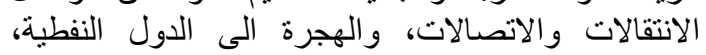
واحلال الميكنة الزراعية محل الالات التقات التقليدية، كل هذه

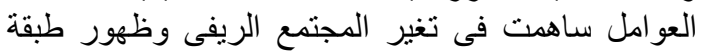

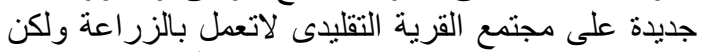

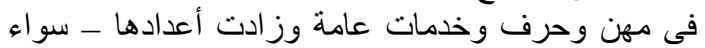

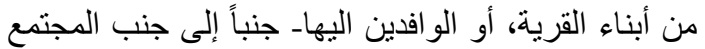

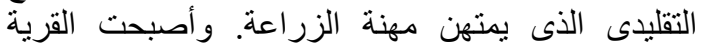

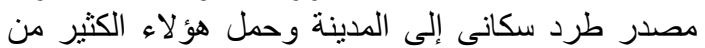
العادات الريفية وظهر هذا في أسلى السئوب استعملاتهم للحيز

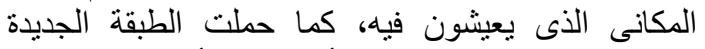

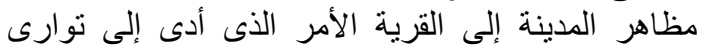

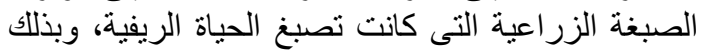
فقدت القرية المصرية لأول مرة في تاريخه الصيا تجانسها الاجتماعى التقليدى.

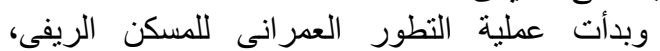

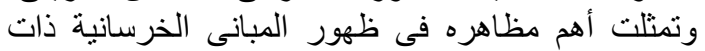

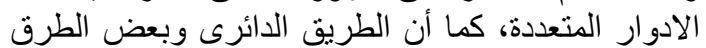

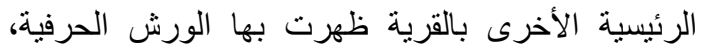

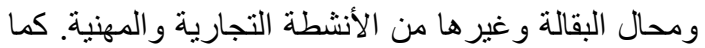

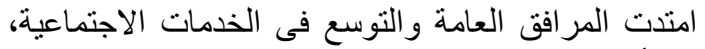

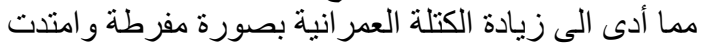
القرى حتى تلاحمت. 


\section{Different dimensions of the rural house development in Sohag governorate}

ـ ـ الحالة الاجتماعية: وقد تم قياسها باستخدام الأرقام التالية:

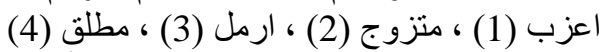

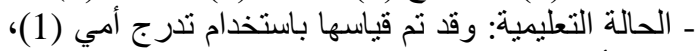

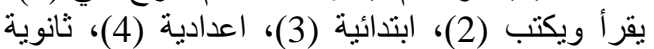
عامة (5)، ثانوية فنية اوصناعية (6)، تعليم عالية أنية

ـ المهنة الاساسية: وقد تم قياسها باعطاء رقم 1 للمهنة

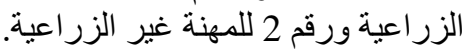

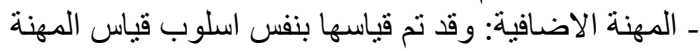

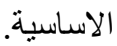

- عدد أفراد الأسرة المعيشية: وقد تم قياسها بالعدد الخام

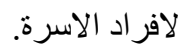

- نوع الاسرة: وقد تم قياسها باستخدام تدرج اسرة بسيطة

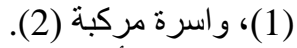

ـ عدد العاطلين بالأسرة وقد تم قياسه بالعدد الخام

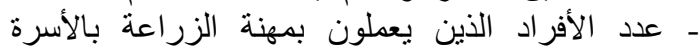
المعيشية: وقد تم قياسه بالعدد الخام

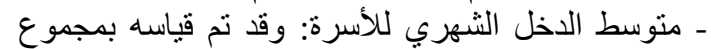
دخول أفراد الأسرة المعيشية منسوبًا إلي إجمالي ليجي

عددهم.

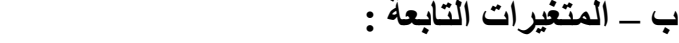

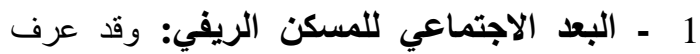
اجرائيا بانه قدرة المسكن الرئي الريفي على الريفي: الوفاء

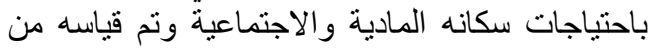

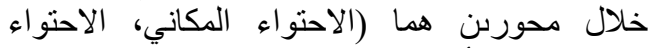

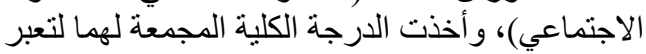

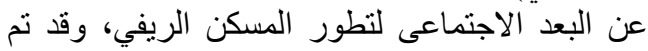

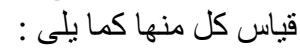

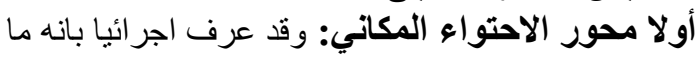

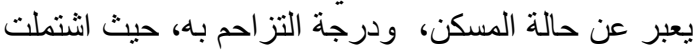

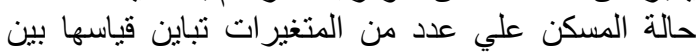

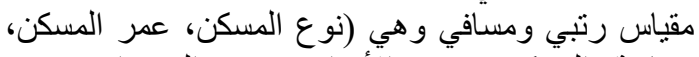

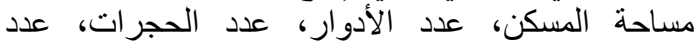

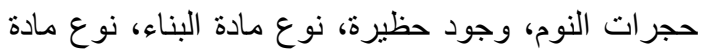

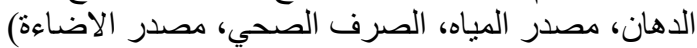
بينما تم قياس درجة التزاحم بقياس عدد الأفراد الذين الذين الذباء

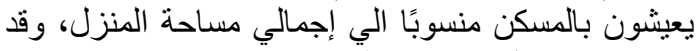

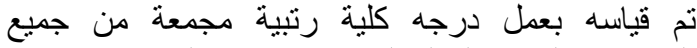

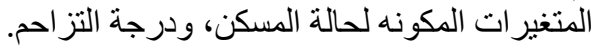

ثانيًا محور الاحتواء الاجتماعي: وقد عرف اجرائيا

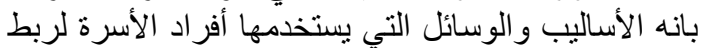
افر ادها ببعضهم البعض وبمجنتمعهم وحمايتهم من الاخطار

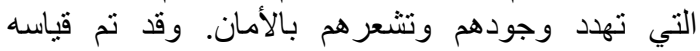

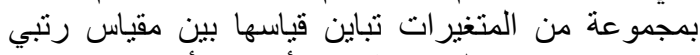
ومسافي وهي ( المشاركة بين أفراد الأسرة الأبرة في اتخاذ

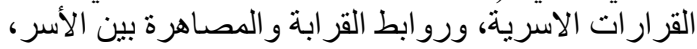

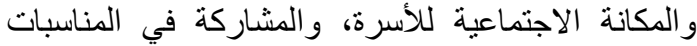
الاسرية والمجتمعية، و عضوية المنظمات، و المشاركة في
ركزت على الجانب العمرانى والندرة النسبية فى الدراسات التى ترصد العلاقة التبادلية التتغيرة بين المسكن

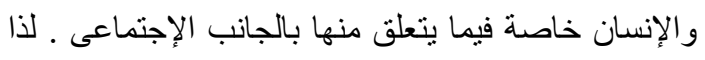

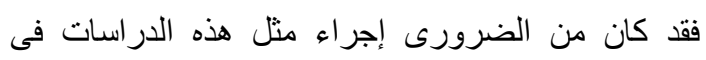
محاولة لإحداث التوازن المنشود بين الجانب العمرانى الجراه و الجانب الإجتماعى للمسكن الريفى.

أهى ضواف البحثلة : البحث السابقة، تم صياغة الأهداف 1 - التعرف على الأبعاد الإجتماعية والبيئية والنفسية و الإقتصادية للمسكن الريفى.

2- التعرف على خصائص ومواصفات للعات المسكن الريفى الحالية بمنطقة البحث.

3- تحديد العلاقة بين المتغيرات المستقلة المدروسة، وكل من الأبعاد المختلفة لنطور المسكن الريفى.

ولتحقيق الهدف الثالث للبحث، تم صياغة الفرض

$$
\text { فرض البحث : }
$$

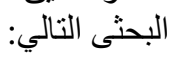

" لالوجد علاقة بين الخصائص السكانية وكل من ولائل الابعاد الاجتماعية، و الاقتصادية، و البيئية، و النفسية لنطور

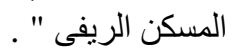

الطريقة البحثية 1 أ - المجال الجغرافي الأية

أجري البحث في محأفظة سوالجئ هاج حيث تمثل الوجها

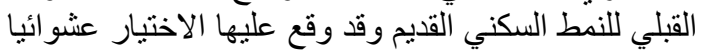

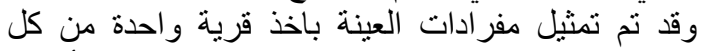
مركز من مر اكز المحافظة البالغة 11 مركز بحتية بحيث أصبح عدد القري في محافظة سو هاج 11 قرية.

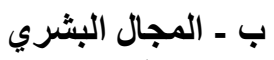
في ظل ظروف جمع البئري البات الميدانية تم أخذ العينة

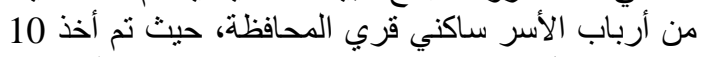

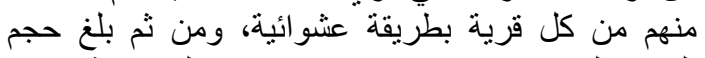
العينه النهائي في ضرية بطري الاستمارات الصحية وندة 110

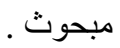
ج- المجال الزمني تم جمع البيانات خلال شهرى أغسطس وسبتمبر 2017

2- التعريفات الإجرائية وقياس المتغيرات: أ ـ المتغيرات المستقلة : الأعرية

ـ السن: وقد تم قياسه بعدد السنوات الميلادية التي ذكرها 
إستخدام الاحصاء الوصفي المتمثل في النسب المئوية

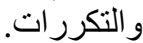

\section{الأهمية التطبيقية للبحث :}

ترجع أهمية هذا البحث إلى أمكانية الحد من المشكلات

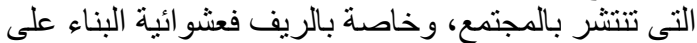

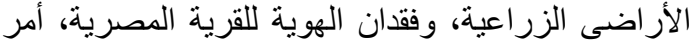

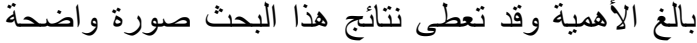

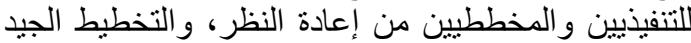

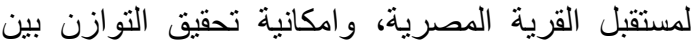

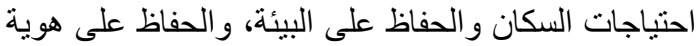

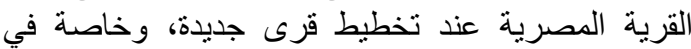
المجتمعات الريفية الجديدة.

\section{وصف خصائص المبحوثين أفراد عينة الدراسة

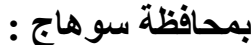

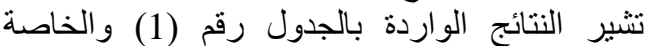

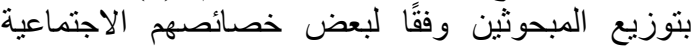
و الاقتصادية بمنطقة البحث بمحافظة سو هاج إلى ما يلى : لئى

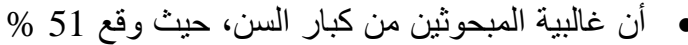
منهم فى الفئة العمرية ( 54 سنة فأكثر.

أن غالبية المبحوثين متزوجين، حيث بلغت نسبتهم 86 \% \%

• أن غالبية المبحوثين أميين بنسبة 40 \% من

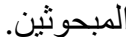
• أن غالبية المبحوثين مهنتهم الأساسية غير زراعية،

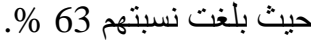
أن غالبية المبحوثين لا توجد لايهم مهن إضافية، حيث

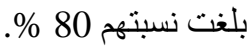
• أن غالبية الأسر من النوع البسيط، حيث بلغت هذه

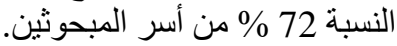

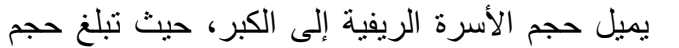

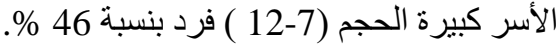

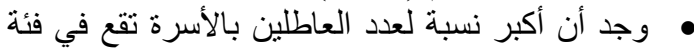
من ( 1-4 فرد ) حيث بلغت 53.6 \% .

مشروعات تتمية القرية)، وقد تم قياسة بعمل درجة كلية

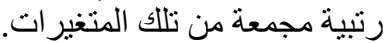
2- البعد البيئى : وقد عرف اجرائيا بأنه عبارة عن كل

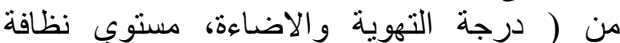
المنزل، كيفية التخلص من القمامة، وجود ولإد حمام

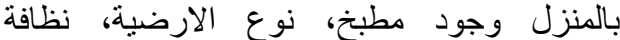

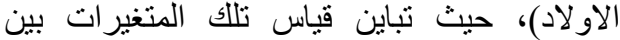

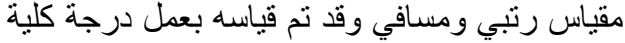
رتبية مجمعة من تللك المتغير ات

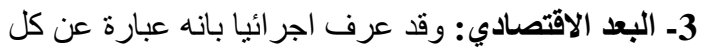

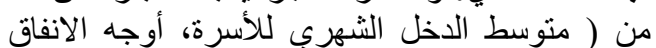

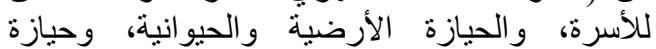
الأجهزة المنزلية وحيازة الالات الزراعة الاعية للأسرة،

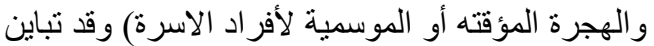
قياس تلالك المتغير ات بين مقياس رتبي ولئ ومسافي حيث نم عمل درجة كلية مجمعة لتلك المتغيرات

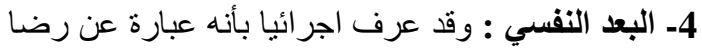

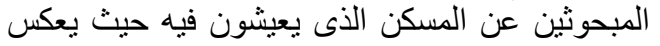
ذللك الرضا مدى راحة المبحوثين واستقر الثين هم بالحياة

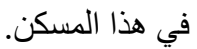

\section{3- معالجة البيانات وتحليلها:}

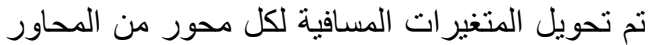

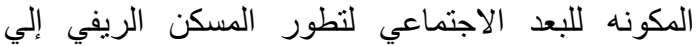

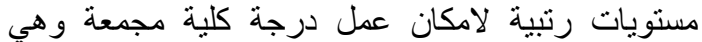

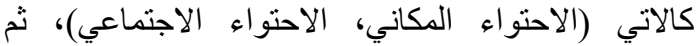

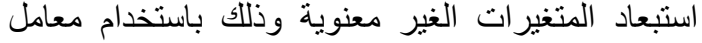

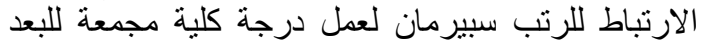

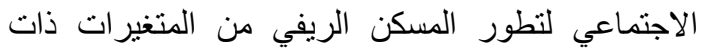

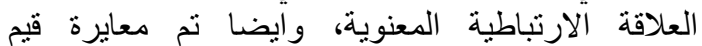

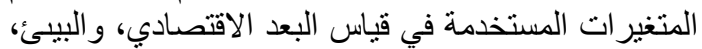

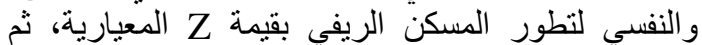

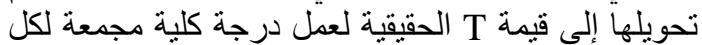

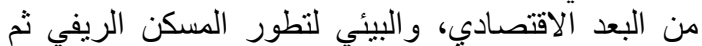

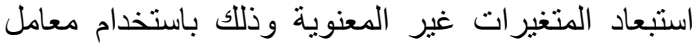

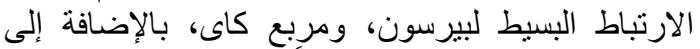

جدول (1): توزيع المبحوثين وفقًا للمتغيرات الثخصية لعينة البحث لإن

\begin{tabular}{|c|c|c|c|c|c|}
\hline$\%$ & 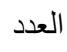 & المتغيرات & $\%$ & 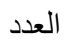 & المتغيرات \\
\hline & & 7 - عدد أفراد الأسرة & & & 1 - سن المبحوث \\
\hline 44 & 48 & 1 - 6 - 6 أفراد & 9 & 10 & 16 - 34 سنة \\
\hline 46 & 51 & | l 7 - 12 فرد & 40 & 44 & 35 - 53 سنة \\
\hline 10 & 11 & 13 فرد فأكثر & 51 & 56 & 54 سنة فأكثر \\
\hline & & 8 - عدد العاطلين بالأسرة & & & 2 - الحالة الإجتماعية : \\
\hline 7 & 8 & لا يوجد & 1 & 1 & أ أعزب \\
\hline 51 & 56 & 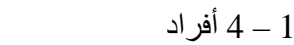 & 86 & 95 & 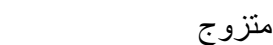 \\
\hline 38 & 42 & 5 & 11 & 12 & 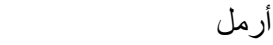 \\
\hline
\end{tabular}


Different dimensions of the rural house development in Sohag governorate

\begin{tabular}{|c|c|c|c|c|c|}
\hline 4 & 4 & 9 أفر اد فأكثر & 2 & 2 & 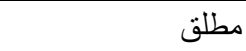 \\
\hline & & 9 - عدد أفراد الأسرة العاملين بالزراعة & & & 3 - الحالة التعليمية \\
\hline 63 & 69 & ل الا يوجد & 40 & 44 & أمى \\
\hline 34 & 37 & 1 - 2 فرد & 17 & 19 & يقر أ ويكتب \\
\hline \multirow[t]{2}{*}{3} & 4 & - 5 - 5 أفراد & 6 & 6 & ابتدائى \\
\hline & & 10 - متوسط الدخل الشهزى لأسرة المبحوث & 1 & 1 & إعدادى \\
\hline 61 & 67 & 160 - 1128 جنيه & 5 & 5 & ثانوى عام \\
\hline 24 & 27 & - 1129 - 2097 جنيه & 16 & 18 & ثنانوى فنى أو صناعى \\
\hline 3 & 3 & 2098 - 3066 جنيه & 15 & 17 & تعليم عالى \\
\hline 5 & 5 & 3067 - 3035 جنيه & & & 4 - المهنة الأساسية \\
\hline \multirow[t]{9}{*}{7} & 8 & 4036 جنيه فأكثر & 37 & 41 & 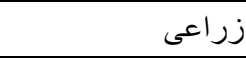 \\
\hline & & & 63 & 69 & غير زر اعى \\
\hline & & & & & 5 - المهنة الإضافية \\
\hline & & & 80 & 88 & لا توجد \\
\hline & & & 13 & 14 & زراعى \\
\hline & & & 7 & 8 & غير زراعى \\
\hline & & & & & 6 - نوع الأسرة \\
\hline & & & 72 & 79 & بسيطة \\
\hline & & & 28 & 31 & مركبة \\
\hline
\end{tabular}

معظم أفراد عينة البحث في الفئة المتوسطة لمحور

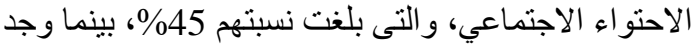
أن 40\% منهح يتركزون في الأئة العليا، 15 \% \% منهم

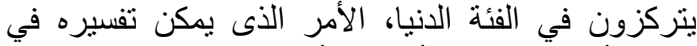

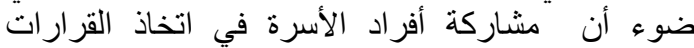

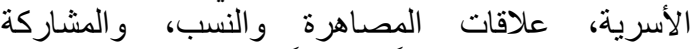
المجتمعية، قد يحقق قدر اً متوسطاً من الإحتو اء الإجتماعى

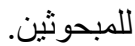

أما بالنسبة لتوزيع المبحوثين وفقًا للبعد المكانى فقد

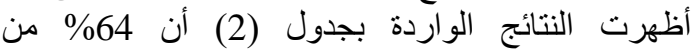

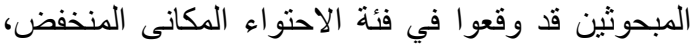

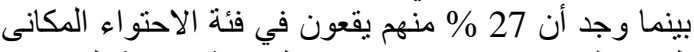

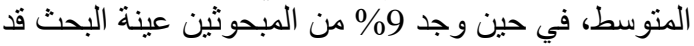
وقعو ا في فئة الاحتو اء المكانى العالى .

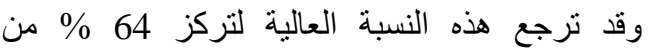

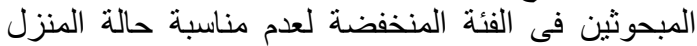

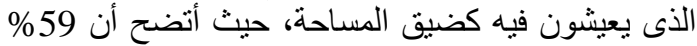

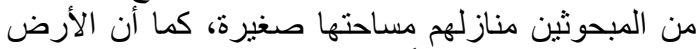
ترابية بمنازلهم، وأيضاً قد يرجع ذلازئ إلى إلى إرتفاع معدل

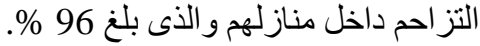

ومن النتائج السابقة يتضح وقوع معظم أفراد عينة

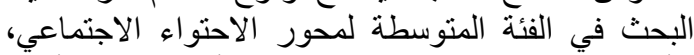

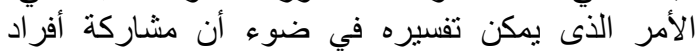

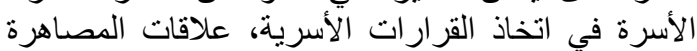

• أن أكبر نسبة لعدد العاملين بالزر اعة وجدت في فئة "

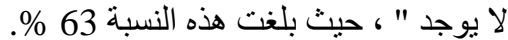

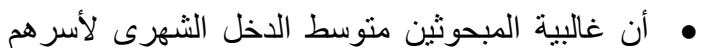

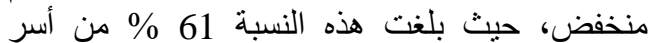

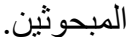
مما سبق يتضح أن مايزيد عن نصف المبحوثين من النين

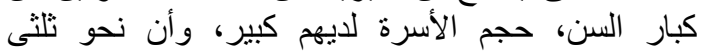
المبحوثين مستوى تعليمهم منخفض، وارة ومن ذوى الانى الحيازة

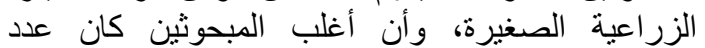

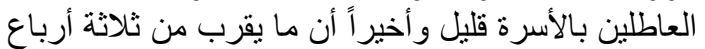

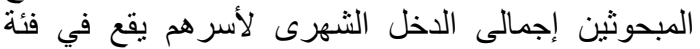

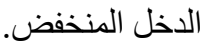

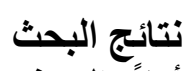
أولاً: التعرف علي الأبعاد الاجتماعية لتطور المسكن

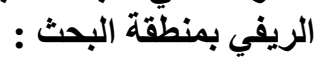

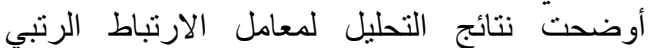

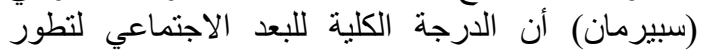

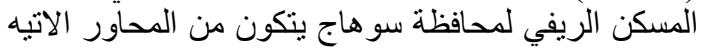

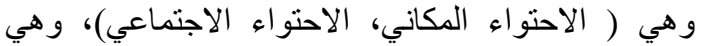

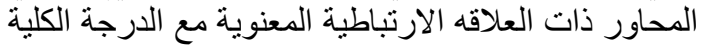

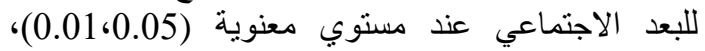

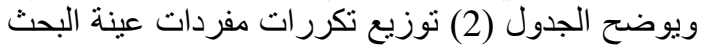

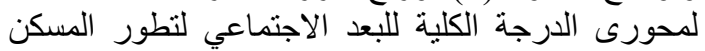

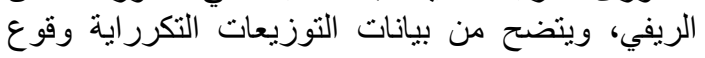


و النسب، والمشاركة المجتمعية، قد يحقق قدراً متوسطاً من الإحتو اء الإجتماعى للمبحوثين. جدول (2): توزيع مفردات عينة البحث وفقًا للارجة الكلية لمحورى البعد الاجتماعي لتطور المسكن الريفي

\begin{tabular}{|c|c|c|c|c|c|c|}
\hline \multicolumn{6}{|c|}{ محافظة سو هاج n=110 } & \multirow{3}{*}{ المحاور } \\
\hline \multicolumn{2}{|c|}{ الفئة العليا } & \multicolumn{2}{|c|}{ الفئة الوسطي } & \multicolumn{2}{|c|}{ الفئة المنخفضة } & \\
\hline$\%$ & عدد & $\%$ & عدد & $\%$ & عدد & \\
\hline 40 & 44 & 45 & 50 & 15 & 16 & الاحتو اء الاجتماعي \\
\hline 9 & 10 & 27 & 30 & 64 & 70 & الاحتو اء المكاني \\
\hline
\end{tabular}

التهوية داخل المسكن، ووجود حمام، ووجود مطبخ، ونظافة المسكن التى توفرت لنسبة كبيرة من المبحوثين.

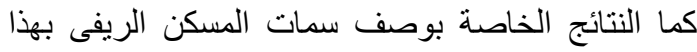

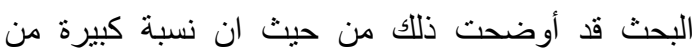

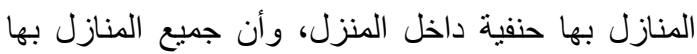
منافذ للتهوية (شباك و احد، أو شباكين ). ثالثاً: التعرف علي البعد النفسي لتطور المسكن

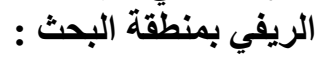

يتضح من بيانات التوزيعات التكرراية للبعد النفسي

و الذى يتمثل في الرضا عن المسكن للمبحوثين بجدول (4) باتئ

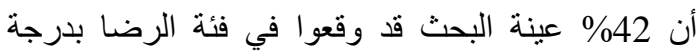
كبيرة ويليهم فئة عدم الرضى و التى بلغت 35 \%٪، بينما تركزت أقل فئة لعينة البحث في الفئة المتوسطة والتى بلغت 23\%، الأمر الذي يمكن تفسيره من خلال توافر بعض الخصائص التى تحقق الراحة النفسية للمبحوثين

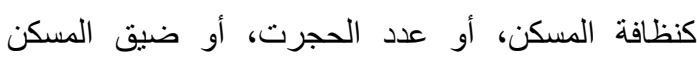
وصغر المساحة التى جعلت نسبة بسيطة من عينة البحث لا تتجاوز نصف العينة في فئة الرضى بدرجة كبيرة، هذا

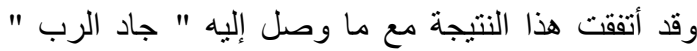

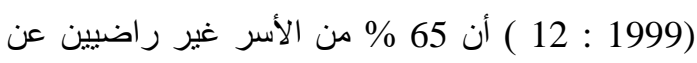

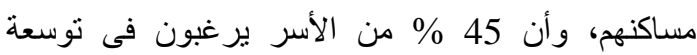

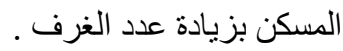

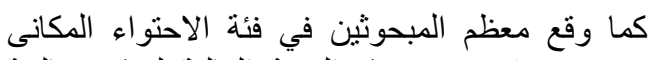

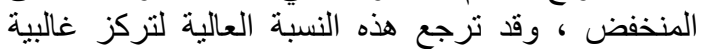

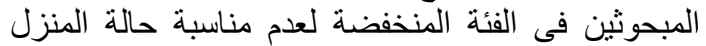

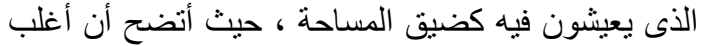

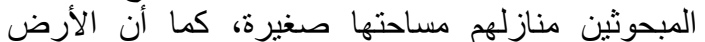
ترابية بمنازلهم ، وأيضاً قد يرجع ذللك إلى إرتفاع معدل الأل

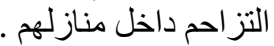

ثانياً: التعرف علي الأبعاد البيئية لتطور المسكن

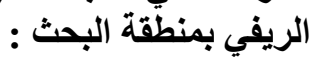

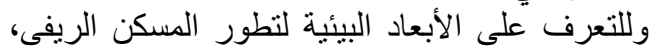

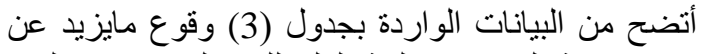
نصف عينة البحث في الفئة العليا للبعد البييئ حيث بلئ بلغت

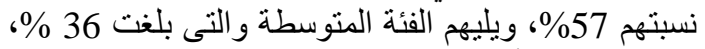

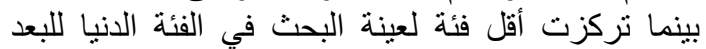

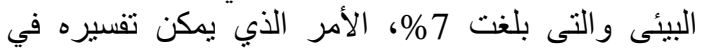
ضوء تو افر المؤشر ات الدالة على الألى حالة المسكن البيئية مثل فئل

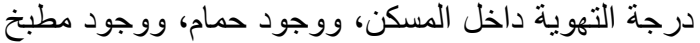
، ونظافة المسكن التى توفرت لنسبة 57 \% من المبحوثين وديخ

ويؤكد هذه النتيجة ما ورد فى جدول ( 6 ) و والخاص بوصف خصائص المسكن الريفى، أن 79 \% من المنازل بها حنفية داخل المنزل ، وأن جميع المنازل بها منافن

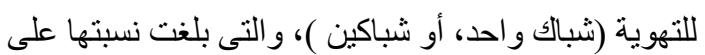

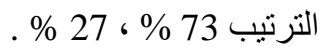

ومن النتائج السابقة تبين غالبية المبحوثين في الفئة

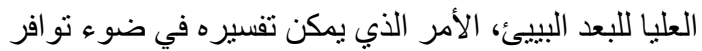

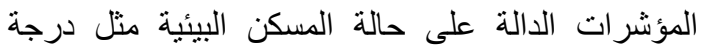
جدول (3): توزيع مفردات عينة البحث وفقًا للبعد البيئي لتطور المسكن الريفي

\begin{tabular}{|c|c|c|}
\hline نسبة & عدد & فئات البعد البيئ \\
\hline 57 & 63 & الفئة العليا \\
\hline 36 & 39 & الفئة المنوسطة \\
\hline 7 & 8 & الفئة الدنبا \\
\hline
\end{tabular}




\begin{tabular}{|c|c|c|c|}
\hline \multicolumn{2}{|c|}{100} & 110 & الاجمالى \\
\hline \multicolumn{4}{|c|}{ جدول (4): توزيع مفردات عنينة البحثث وفقًا للبعد النفسي ( الرضان عن المسكن ) بمنطقة البحث } \\
\hline$\%$ & عدد عد & & فئات البعد النفسي \\
\hline 42 & 46 & & ر اضى بدرجة كبيرة \\
\hline 23 & 25 & & ر اضى بدرجة متوسطة \\
\hline 35 & 39 & & غير راضى \\
\hline 100 & 110 & & الاجمالى \\
\hline
\end{tabular}

جمعت وحسبت من استمارة الاستبيان

مفردات عينة البحث للمؤشرات المعنوية المكونة للارجة الكلية للبعد الاقتصادي لتطور المسكن الريفي.

حيث تبين من هذه النتائج وقوع المبحوثين أفراد عينة البحث فى الفئة المنخفضة لهذه المؤشرات حيث بلغت النسب على الترتيب كالآتى : اوجه الانفاق 86 \%؛، حجم حيازة الارض الزراعية 99 \% ، حجم الحيازة الحيوانية 98 \% ، حجم حيازة الاجهزة المنزلية 99 \% ، حجم حيازة الالات الزراعية 92 \% ، متوسط الدخل الثهري للاسرة 86 \% ، و الهجرة المؤقته أو الموسمية بالداخل أو

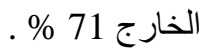

وتشير النتائج السابقة إلي أن معظم مفردات العينة

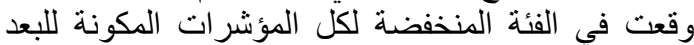

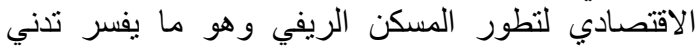
المستوي الاقتصادي للعينة البحثية . لإني

وللتعرف على الدرجة الكلية للبعد الإقتصادى، أشارت البيانات الواردة بجدول (6) أن معظم أفر اد عينة البحث قد تركزوا في الفئة المنخفضة للارجة الكلية للبعد الاقتصادي لتطور المسكن الريفي بنسبة بلغت 84\%، في حين 13\% من المبحوثين قد وقعوا في الفئة الوسطى، و3 \% من المبحوثين عينة البحث قد وقعو ا في الفئة العليا.

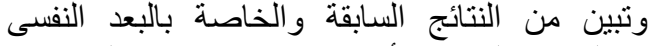
لتطور المسكن الريفى ، أن مايقرب من نصف المنابعة المبحوثين

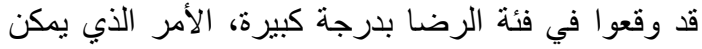

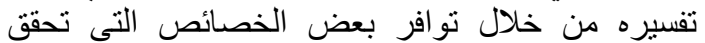

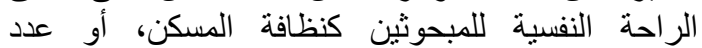

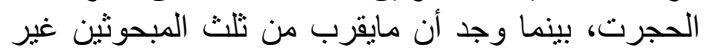
راضبين وقد برجع ذلك إلى ضيق المسكن أوصغر مساحة

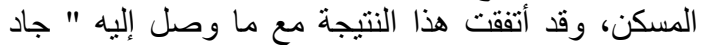

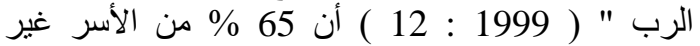

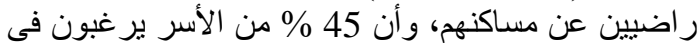
توسعة المسكن بزيادة عدد الغرف ـاكن

رابعاً: التعرف علي الأبعاد الاقتصادية لتطور المسكن الريفي بمنطقة البحث الابعاد الأهي

تم تناول هذا البعد من خلال مجموعة من المؤشرات، حيث أوضحت نتائج التحليل لمعامل الارتباط البسيط (بيرسون) أن الدرجة الكلية للبعد الاقتصادي لتطور المسكن الريفي لمحافظة سوهاج يتكون من المؤشرات الاتيه وهي (اوجه الانفاق، حجم حيازة الارض الزر اعية، حجم الحيازة الحيوانية، حجم حيازة الاجهزة المنزلية، حجم حيازة الالات الزراعية، متوسط الاخل الثهري للاسرة، والهجرة المؤقته أو الموسمية بالداخل أو الخارج) وهي المؤشرات ذات العلاقه الارتباطية المعنوية مع الدرجة الكلية للبعد الاقتصادي عند مستوي معنوية (0.05،0.01)، ويوضح الجدول (5) توزيعات تكررات

جدول (5): توزيعات تكرارات مفردات عينة البحث وفقًا للمؤشرات المعنوية للارجة الكلية للبعد الاقتصادي لتطور المسكن الريفي بمحافظة سوهات كوات مفردات

$$
110=0
$$


Zeinab A. Abdel Hamid

\begin{tabular}{|c|c|c|c|c|c|c|}
\hline \multicolumn{2}{|c|}{ الفئة العليا } & \multicolumn{2}{|c|}{ الفئة المتوسطة } & \multicolumn{2}{|c|}{ الفئة المنخفضة } & \\
\hline$\%$ & عدد & $\%$ & 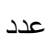 & $\%$ & 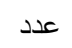 & \\
\hline 3 & 4 & 11 & 12 & 86 & 94 & أوجه الانفاق داخل الأسرة \\
\hline 1 & 1 & 0 & 0 & 99 & 109 & حجم الحيازة الأرضية \\
\hline 4 & 4 & 7 & 8 & 89 & 98 & حجم الحيازة الحيو انية \\
\hline 1 & 1 & 0 & 0 & 99 & 109 & حجم حيازة الاجهزة المنزلية \\
\hline 1 & 1 & 7 & 8 & 92 & 101 & حجم حيازة الالات الزر اعية \\
\hline 2 & 3 & 12 & 13 & 86 & 94 & متوسط الدخل الثهري للاسرة \\
\hline 23 & 25 & 6 & 7 & 71 & 78 & الهجرة المؤقته او الموسمية بالداخل \\
\hline
\end{tabular}

جمعت وحسبت من استمارة الاستبيان

جدول (6): توزيع مفردات العينة وفقًا للارجة الكلية للبعد الاقتصادي لتطور المسكن الريفي

\begin{tabular}{|c|c|c|}
\hline$\%$ & تكر ار ن = 110 & الفئات \\
\hline 84 & 92 & الفئة المنخفضة \\
\hline 13 & 14 & الفئة الوسطي \\
\hline 3 & 4 & الفئة العلبيا \\
\hline
\end{tabular}

خامساً: خصائص ومواصفات المسكن الريفي

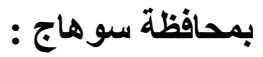

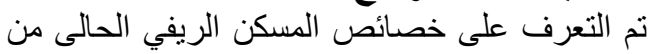

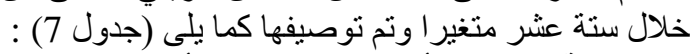

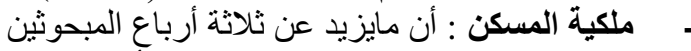

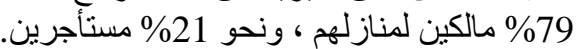

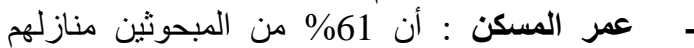

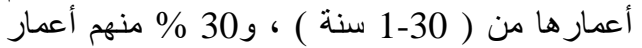

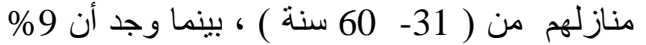

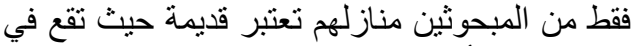

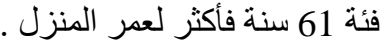

وقد تفسر النتائج السابقة بأن البعد الاقتصادي يسهح بنسبة ضئيلة في نطور المسكن الريفي بمنطقة البحث حيث وجد أن جميع مؤشرات البعد الاقتصادى تقع في الفئة المنخفضة من حجم الحيازة المزرعية، والحيوانية، والالات الزراعية، والمنزلية، وتدنى متوسط الدخل الثهرى للأسرة، الهجرة المؤقته او الموسمية بالداخل

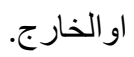

جدول (7): توزيع مفردات عينة البحث وفقًا لخصائص ومواصفات المسكن الريفي

\begin{tabular}{|c|c|c|}
\hline$\%$ & العدد & خصائص السكن \\
\hline & & 1- نوع المسكن \\
\hline 20 & 22 & إيجار \\
\hline 80 & 88 & ملك ملك ما مالك \\
\hline & & 2- عمر المسكن \\
\hline 61 & 67 & 1 - 30 سنة \\
\hline 30 & 33 & 31 - 60 سنة \\
\hline 9 & 10 & 61 سنة فأكثر \\
\hline & & 3- مساحة المسكن \\
\hline 59 & 65 & 40 - 155 منر \\
\hline 28 & 31 & 156 - 271 متر \\
\hline
\end{tabular}


Different dimensions of the rural house development in Sohag governorate

\begin{tabular}{|c|c|c|}
\hline 6 & 7 & ا 387 - 387 متر \\
\hline \multirow[t]{2}{*}{5} & 6 & 388 - 503 متر \\
\hline & & 4- ل حالة المسكن \\
\hline 48 & 53 & قديم \\
\hline 30 & 33 & أعبد بناءه \\
\hline \multirow[t]{2}{*}{22} & 24 & حديث \\
\hline & & 5- عدد الأدوار بالمسكن \\
\hline 35 & 38 & ا دور واحد \\
\hline 50 & 55 & ( \\
\hline \multirow[t]{2}{*}{15} & 17 & ثلاث أدوار \\
\hline & & 6- عدد الحجرات بالمسكن \\
\hline 60 & 66 & ا 5 - 5 حجرة \\
\hline 25 & 27 & 6 - 10 حجرة \\
\hline \multirow[t]{2}{*}{15} & 17 & ا 11 - 15 حجرة \\
\hline & & 7 - 7 - وجود مطبخ \\
\hline 72 & 79 & | بوجد \\
\hline \multirow[t]{2}{*}{28} & 31 & ل الايوجد \\
\hline & & 8- وجود حظيرة \\
\hline 35 & 38 & حظيرة داخل المسكن \\
\hline 23 & 25 & حظيرة خارج المسكن \\
\hline \multirow[t]{2}{*}{42} & 47 & ل الا توجد \\
\hline & 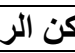 & تابع جدول (7) توزيع مفردات عينة \\
\hline \multirow[t]{2}{*}{$\%$} & 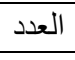 & خصائص المسكن \\
\hline & & 9ـ نوع الاهان بالمسكن \\
\hline 14 & 15 & دهاكة طينية \\
\hline 54 & 60 & 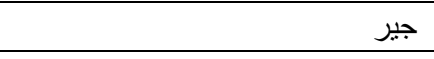 \\
\hline 11 & 12 & 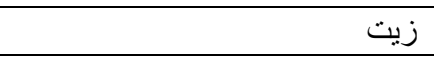 \\
\hline \multirow[t]{2}{*}{21} & 23 & بلاستيك \\
\hline & & 10- نوع أرضية المسكن \\
\hline 59 & 65 & ترابية \\
\hline 7 & 8 & اسمنتية \\
\hline \multirow[t]{2}{*}{34} & 37 & بلاط \\
\hline & & 11- مصدر الحصول على المياة \\
\hline 9 & 10 & طلمبة خارجية \\
\hline 12 & 13 & حنفية عمومية \\
\hline \multirow[t]{2}{*}{79} & 87 & حنفية داخل المسكن \\
\hline & & 12 ـ حالة الصرف الصحى بالمسكن \\
\hline 95 & 104 & | طرنش \\
\hline \multirow[t]{2}{*}{5} & 6 & صرف صحى \\
\hline & & 13- درجة التزاحم بالمسكن \\
\hline 96 & 106 & درجة تز احم عالية \\
\hline 2 & 2 & مرجة تز احم متوسطة \\
\hline \multirow[t]{2}{*}{2} & 2 & مرجة تز احم قليلة \\
\hline & & 14- درجة التهوية بالمسكن \\
\hline 73 & 80 & شباك واحد \\
\hline
\end{tabular}


Zeinab A. Abdel Hamid

\begin{tabular}{|c|c|c|}
\hline 27 & 30 & 2 شبالك \\
\hline & & 15 - نظافة المسكن \\
\hline 10 & 10 & سيئة \\
\hline 41 & 45 & متوسطة \\
\hline \multirow[t]{2}{*}{49} & 54 & جيدة \\
\hline & & 16 - وجود حمام \\
\hline 86 & 94 & يوجد \\
\hline 14 & 16 & لا يوجد \\
\hline
\end{tabular}

- - نوع أرضية المسكن : وجد أن 59 \% من المنازل نوع الأرضية بها نرابية ، 7 \% منها الأرضية أسمنتية، بينما 34\% من المنازل أرضيتها بلاط (شكل رقم 2 ). ونسبة الأرضية التربية لا تز ال كبيرة فى ضوء الحفاظ على نظافة المسكن . مصدر مياة الثرب : تثير نتائج البحث أن 9 \% من المبحوثين يحصلون على المياة من طلمبة خارجية ، في حين أن 12 \% من المبحوثين بحصلون على بلى المياة من حنفية عمومية ، 79\% منهم لديهم حنفية

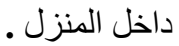
- درجة التهوية : وجد أن 73 \% من غرف المنازل بها شباك واحد ، في حين أن 26 \% من المبحوثين

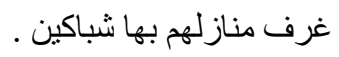
درجة التزاحم داخل المنازل : تظهر البيانات أن 96 من المبحوثين درجة التزاحم داخل منازلهم عالية، بينما 2 \% منهم درجة التزاحم بها منوسطة ، 2 \% منهم درجة التز احم بمناز لهم قليلة . نظافة المسكن : بينت النتائج حسبما ذكر المبحوثين أن 49 \% منهم قد أقروت بأن مساكنهم جيدة ، بينما ذكر 41 \% منهم بأن مساكنهم منوسطة ، فى حئ حين

$$
\text { بين } 10 \text { \% منهم بأن مساكنهم سيئة. }
$$

وجود حمام : أقر 86 \% من المبحوثين أفراد عينة البحث

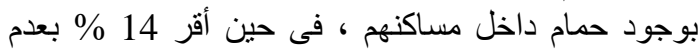

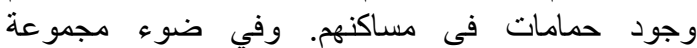
الخصائص السابقة للمسكن الريفي يشير راجح (2007، 317 ) أن كثيرًا من المساكن الجديدة تتسم بصغر مساحة
مساحة المسكن : أن 60 \% من المبحوثين يتركزون

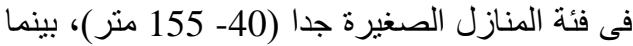
28 \% منهم يقع فى فئة المنازل منوسطة المساحة )

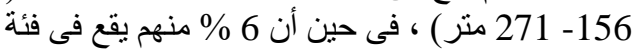

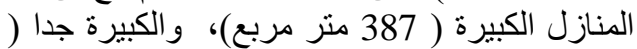
من 388- 503 منر مربع ).

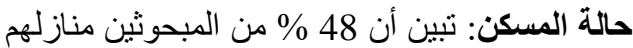
قديمة، بينما 31 \% منهم مناز لهم أعيد بنائها من جديد من اليداء ، 21 \% مناز لهم حديثة البناء. عدد الأدوار : وجد أن 35 \% من من المبحوثين مناز لهم

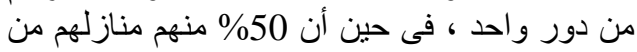
دورين ، بينما 15 \% منهم منازلهم مكونة من ثناز مناثة

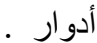
عدد الحجرات : أظهرت البيانات أن 60 \% من من

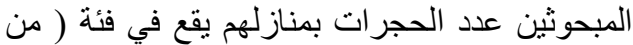

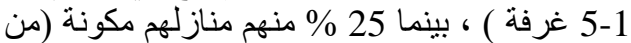

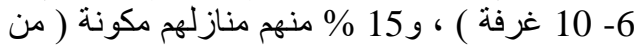

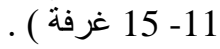
وجود مطبخ : أن 72 \% من المنازل يوجد بها مطبخ

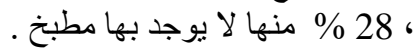

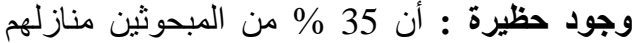
يوجد بها حظيرة داخل المنزل، بينما 23 \% \% منهر

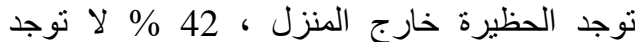
حظيرة لديهم . ـ نوع ملكية المنزل : نتير نتائج البحث أن 79 \% من من

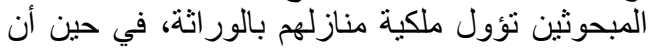

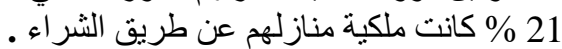
- - نوع الدهان : أظهرت البيانات أن 14 \% من المبحوثين نوع دهان مناز لهم دهاكة طينية، بينما 54 \% منهم منازلهم دهانها من الجير، و11 \% منهم منازلهم دهانها من الزيت، 21 \% من المبحوثين

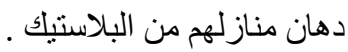




\section{Different dimensions of the rural house development in Sohag governorate}

- وجود علاقة ارتباطية عند مستوى 0.01 بين متغيرات

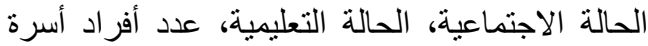

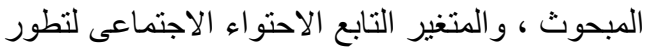

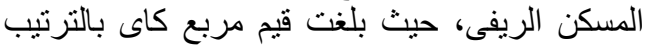

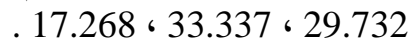

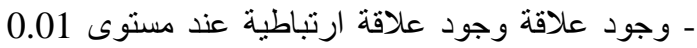

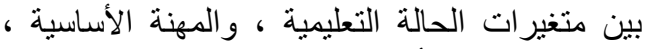

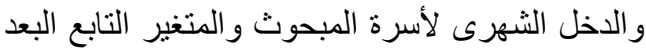

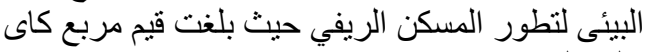

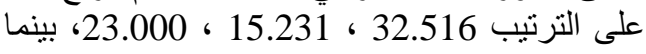
وجدت علاقة ارتباطبة عند 0.05 بين متغير سن البن البن المبحوث والمتغير التابع البعد البيئي لتطور المسكن

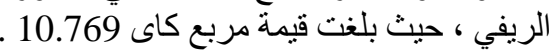
ـ وجود علاقة ارتباطية عند مستوى مليع كان 0.01 بين متغيرات الحالة التعليمية، والمهنة الأساسية ، و والدخل الثنهرى

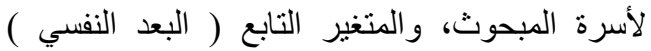

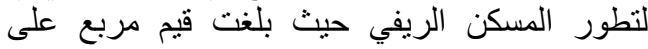

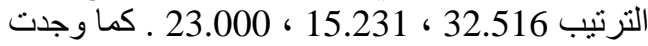
علاقة ارتباطية عند مستوى 0.05 بين متغير السن، والمتغير التابع (البعد النفسي) حيث بلغت قيمة مربع

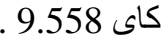

- وجود علاقة ارتباطية عند مستوى 0.01 بين متغيرات

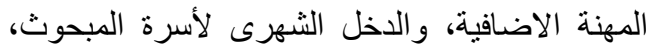

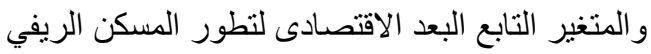

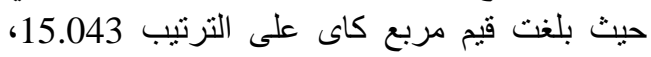

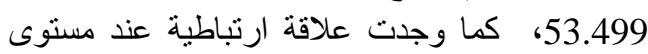
0.05 بين متغيرى نوع الأسرة، و عدد أفراد الأسرة الأسرة،

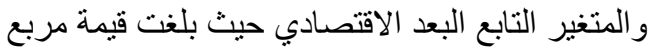

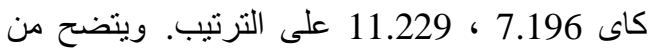

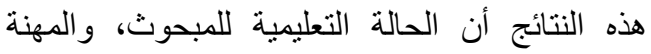

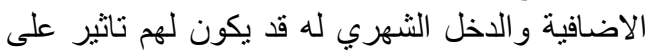

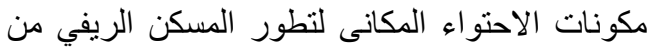

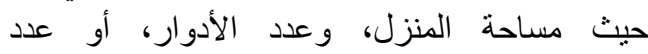

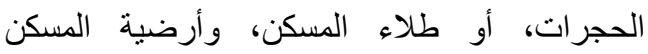

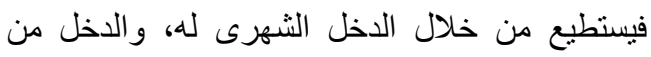

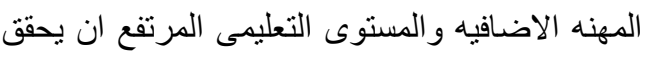
توفر هذه المكونات ويحقق الاحتواء المكانى لتطور التون

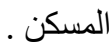

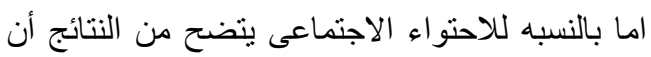

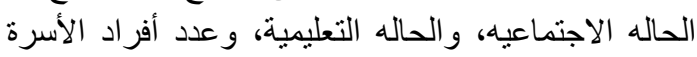

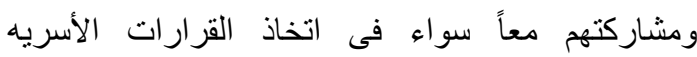

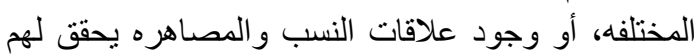
تو افر الاحتو اء الاجتماعى للمسكن.

وفيما يتعلق بالبعد البيئى فقد وجد أن الحالة التعليمية،

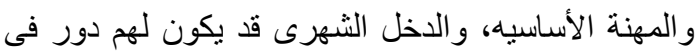
تو افر مقومات البيئة الصحية السليمة من التهويه للمنزل

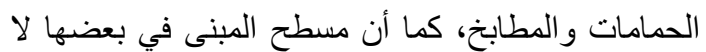

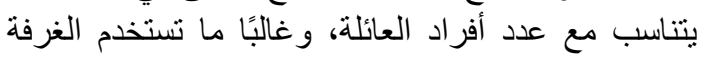

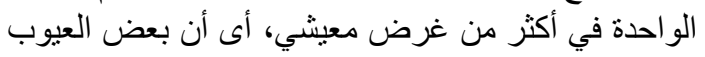

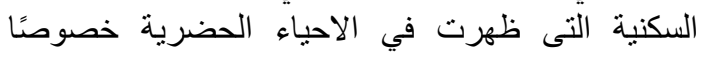
الاحياء العشو ائية قد ظهرت واضحة في في الاحياء في الاسكان الريفي،

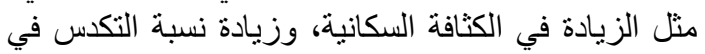
(elhefnawi : الغرفة الواحدة. ويضيف الحفناون siteresources.worldbank.org,p.7- 10- 2017 )

أن التلوث في المناطق الريفية زاد نتيجة التغير في أنشطة القرية، و انتشار ركوب السيار ات التئ

ومن النتائج السابقة والخاصة بمو اصفات وخصائص النص

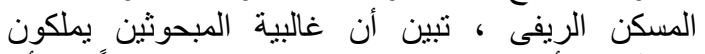

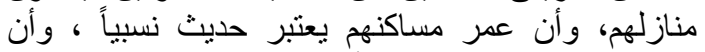
مساحة المساكن صغيرة ، و وأن المساكن تتكون من دون دورين

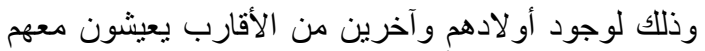

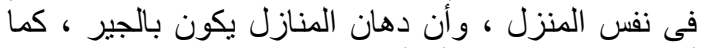

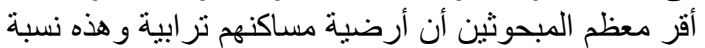

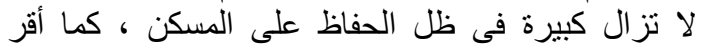

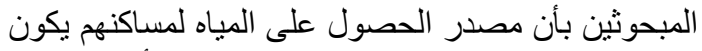

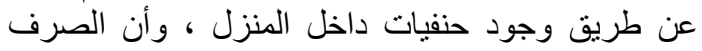

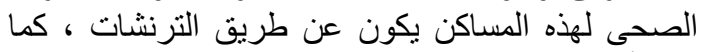

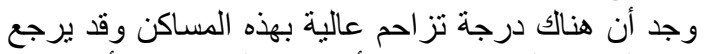

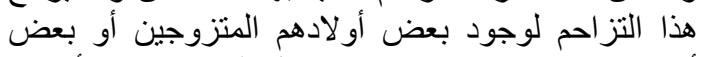

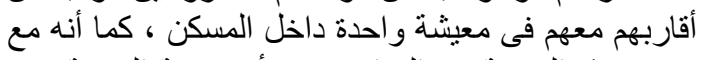

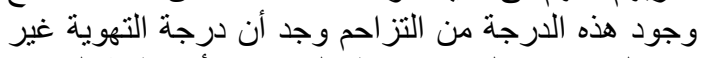
جيدة لوجودة شباك واحد فقط بالمسكن، وأن وأن نظافة المسكن لايهم جيدة ، وأن مساكنهم بها حمامات.

سادساً: العلاقة بين بعض المتغيرات المستقلة المدروسة وكلة من الإينة ولابعاد الاجتماعية والاقتصادية والبيئية والنفسية لنطية لتطور

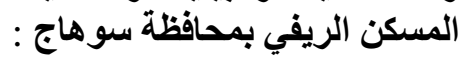

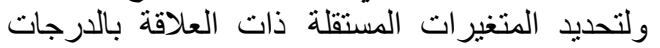
الكلية للابعاد الاجتماعية والاقتصادية والبيئية والنفية كالنفية

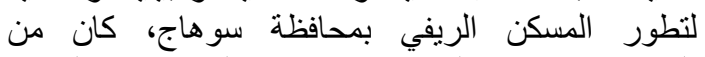

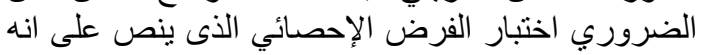

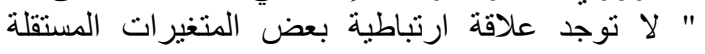
ودرجات الابعاد الاجتماعية و الاقتصادية و البيئية و النفسية لئية لتطور المسكن الريفي بمحافظة سو هاج ".

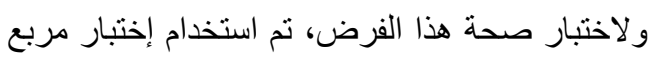
كاى ، وقد توصلت الدراسة إلى النتائج التالية الذوضحة مربح

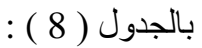
- وجود علاقة ارتباطية عند مستوى 0.01 بين متغيرات الحالة التعليمية ، و المهنة الإضافية ، والدئ والدخل الثنهري

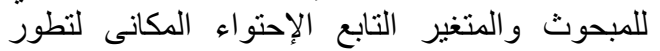

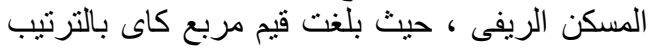
. 15.784 ، 14.732 


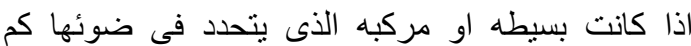

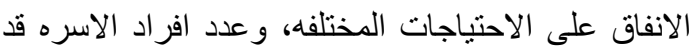

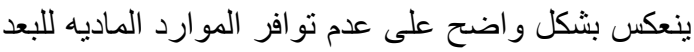
الاقتصادى لتطور المسكن الريفى .

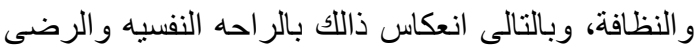

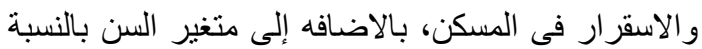

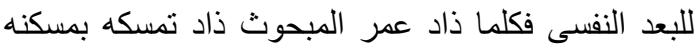
وشعر بالر احه و الطمائنينه بالحياه فيه

أما بالنسبه إلى البعد الاقصادى فقد وجد ان المهنه

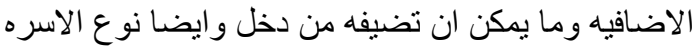

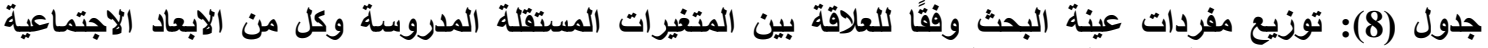

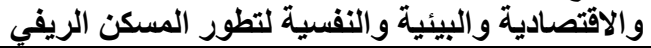

\begin{tabular}{|c|c|c|c|c|c|}
\hline البعد الاقتصنادى & البعد النفسي & البعد البيئي & الاجتماعو اءى & الاحتو اء المكانى & المتغير ات \\
\hline 6.203 & *9.558 & 5.037 & 5.016 & 1.777 & 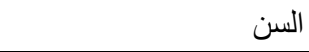 \\
\hline 0.827 & 10.087 & 3.398 & **29.732 & 4.716 & الحالة الاجتماعية \\
\hline 19.395 & $* * 32.516$ & **29.372 & **33.337 & **29.732 & الحالة التعليمية \\
\hline 1.216 & **15.231 & **12.044 & 3.667 & 3.095 & المهنة الاساسية \\
\hline$* * 15.034$ & 4.669 & 1.109 & 5.697 & $* * 14.820$ & المهنة الاضافية \\
\hline *7.196 & 0.948 & 2.837 & 6.650 & 16.500 & نوع الأسرة \\
\hline *11.229 & 2.379 & 2.145 & $* * 17.268$ & 7.662 & عدد أفر اد الأسرة \\
\hline 1.160 & 4.355 & 3.124 & 3.474 & 1.567 & منوسط أعمار أفراد الأسرة \\
\hline$* * 53.499$ & $* * 23.000$ & *10.769 & 7.735 & $* * 15.784$ & الاخل الشهري \\
\hline
\end{tabular}

المعاصر في العالم الاسلامى، كلية الهنسة ، جامعة

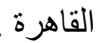
جاد الرب، محمد عبد الوهاب، 1999 ، در اسة الأسرة

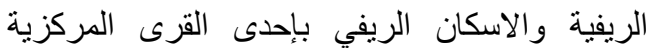

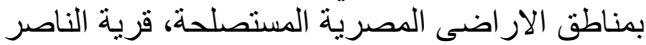

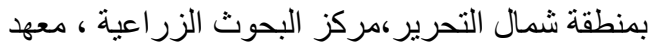
بحوث الارشاد الزر اعى و التتمية الريفية ، نشرة بحثية

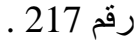
راجح، أبو زيد، العمران المصري - رصد التطورات في عمران أرض مصر العران في أواخر القرن العشرئ العشرين

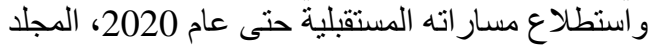

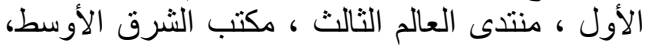

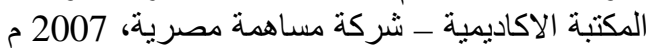

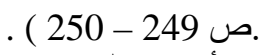

علام، أحمد خالد، واسماعيل عبد العزيز عامر، العيل 2500

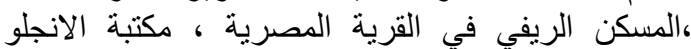

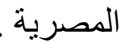

- Abd Allah,H,F,2009, Architecture of communities with Specific Cultural Patterns "Methology for Evaluating the Nubian Relocation Projects From the Perspective of Socio- Cultural Dimensions "Faculty of Engineering , Cairo University .

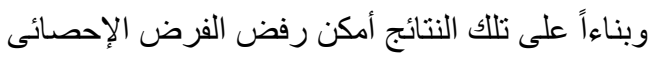

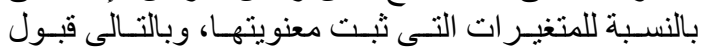

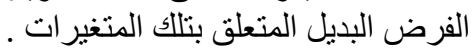

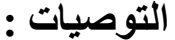

فى ضوء نتائج الدراسة يمكن الخروج بالتوصيات التالية:

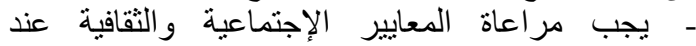
التخطيط لبناء قرى جديدة من حيث المساحة المناسية المباءية

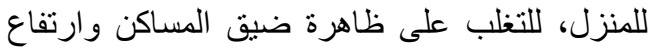

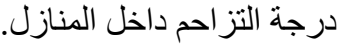
- دعم الأسر الريفية بالمعلومات نحو أهمية المشاركة

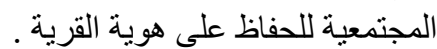

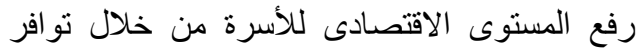
بعض الششروعات التى تدر الدخل، وبالتالى تحسين

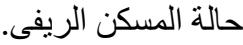

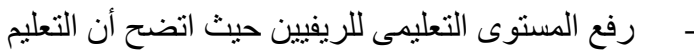
عامل مؤثر فى تطور المسكن الريفى.

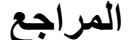

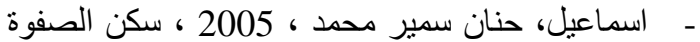

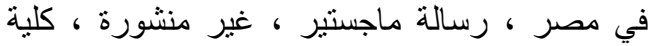

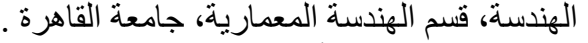

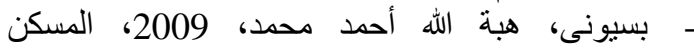
المعاصر بين المنية المنلبات المادية و الاحتياجات الانسانية، دراسة جدلية المادى و الانسانى على المسكن 


\title{
Different dimensions of the rural house development in Sohag governorate
}

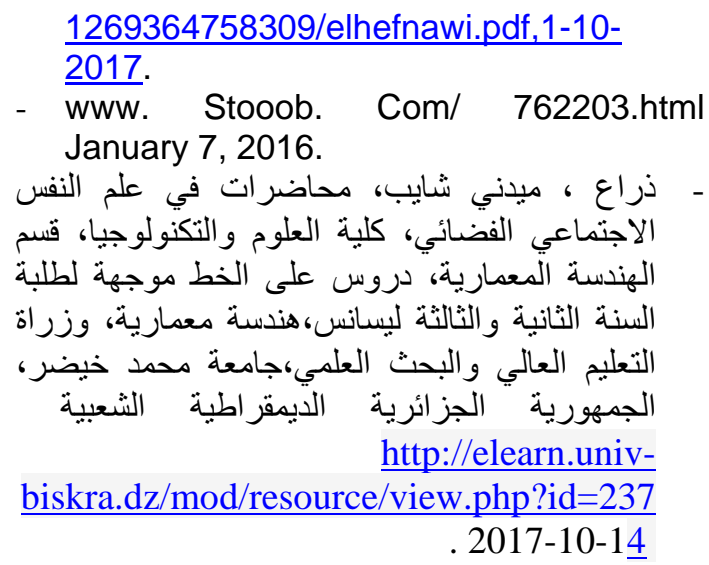

1269364758309/elhefnawi.pdf,1-102017.

- www. Stooob. Com/ 762203.html January 7, 2016.

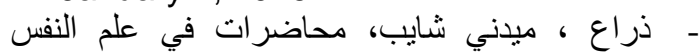

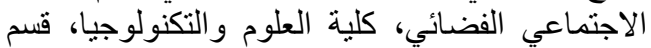

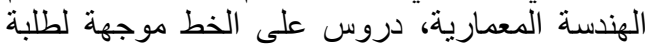

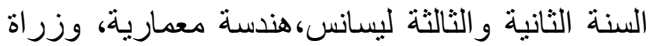

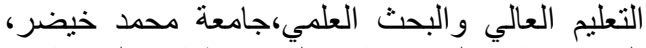

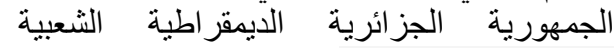

http://elearn.univ-

biskra.dz/mod/resource/view.php?id=237

. 2017-10-14

- El Hefnawi ,A, "Protecting" agricultural land from urbanization or "Managing" the conflict between informal urban growth while meeting the demands of the communities (Lessons learnt from the Egyptian policy reforms) Housing and Building Research centre, Urban Training and studies Institute, Egypt.Ministry of housing Utilities and Urban Communities.

- http://siteresources.worldbank.org/INTUR BANDEVELOPMENT/Resources/336387 -1269364699096/6892630-

\section{DIFFERENT DIMENSIONS OF THE RURAL HOUSE DEVELOPMENT IN SOHAG GOVERNORATE}

\author{
Zeinab A. Abdel Hamid \\ Senior Researcher - Agricultural Extension \& Rural Development Research Institute \\ (AERDRI), Agricultural Research Center, Giza, Egypt \\ Rural Society Research Department
}

\begin{abstract}
This research aims at identifying the social, environmental, psychological and economic dimensions of the rural house in the research area; identifying the characteristics and specifications of the current rural house or dwelling in the research area; finally determining the relationship between the independent variables and each different dimensions of the rural house development.

This research was carried out in Sohag governorate, and selected one village from each district which they are 11 districts, thus the number of selected villages were in Sohag governorate reached 11 villages. The data were collected from household heads who lived in selected villages during August 2017, which were selected 10 individuals from each village randomly; so the total size sample was reached 110 respondents collected through personal interview by using a questionnaires. To analyze the data statistically used: the Spearman correlation coefficients, $Z$ standard, Pearson's simple correlation coefficient, and chi-square, also were used the descriptive statistics which are percentages and frequencies.

The research found the following results:

- Most of the respondents were founded the follows: in the middle class of the social containment dimension; in the low spatial containment category; and in the high category of environmental dimension of the rural house development in the research area.

- The majority of respondents were founded in the high category of psychological satisfaction, and in the low category of the economic dimension.

- There was a correlation relationship at the significance level 0.01 between the spatial dimension of rural house development and the following independent variables: the educational status; the additional occupation; and the respondent monthly income.

- There was a correlation relationship at the significance level 0.01 between the social dimension of rural house development and the following independent variables that are the educational status; the social status; the number of family members.

- There was a correlation relationship at the significance level 0.01 between the environmental dimension of the rural house and the following independent variables that are: the educational status; the basic occupation; and the respondent monthly income.
\end{abstract}




\section{Zeinab A. Abdel Hamid}

- There was a correlation relationship at the significance level 0.05 between the psychological satisfaction of rural house development and the following independent variables that are: the educational status; the basic occupation; the respondent monthly income.

- There was a correlation relationship at the significance level 0.01 between the economic dimension of rural house development and the following independent variables: the additional occupation; and the respondent monthly income. Also there was a correlation relationship at the significant level 0.05 between the economic dimension of rural house development and the independent variables that are: family type; and the number of family respondent members.

Key words: Social Dimensions - Rural house development - Rural development. 